\title{
PHYSIOLOGICAL AND BIOCHEMICAL INFLUENCES OF SOME SAFETY TREATMENTS ON ONION PLANTS
}

\author{
A. Midan, M. A. Fattah Allah, Sally A. Midan and Alaa K. A. El - Nemr \\ Horticulture Department, Faculty of Agriculture, University of Menoufia, Shebin El-Kom, Egypt.
}

Received: May 25, 2017

Accepted: Aug. 29, 2017

\begin{abstract}
Effects of five different non-traditional treatments i.e. magnetic water, humic acid, seaweeds extracts, mycorrhzyia fungi and organic fertilizers in addition to the traditional mineral recommended fertilizer were determined in aspect to different growth characteristics within onion plants grown in two subsequent seasons under open field conditions in station of faculty of agricultural at minufiya university. The correlation between of the tested treatments and the accumulation of different biochemical active compounds within treated onion such as ploy phenols, and peroxidases substrates were investigated through using HPLC apparatus. The results showed that the highest recorded growth and vegetative criteria were observed on plants treated with mycorrhyza fungi followed by magnetized water. On contrary, the lowest growth and vegetative values were recorded by organic fertilizers and traditional recommend fertilizers. Biochemical analysis using HPLC revealed that cinamic acid substrate was detected only within treated plants by sea weeds extracts, humic acid and recommended mineral fertilizers. The highest accumulation of peroxidase enzyme was observed with mycorrhyza and sea weeds treatments. The results showed also that Mycorrhyza fungi, sea weeds extracts, organic fertilizers in addition to recommend mono fertilizers increased the accumulation of poly phenols substrates more than all other tested treatments.
\end{abstract}

Key words: Onion - Mycorrhyza- magnetized water- seaweds extracts - humic acid.

\section{INTRODUCTION}

Onion ( Allium Cepa L.) being among the most widely distributed Liliaceous plants in world. Besides, the onion is a species of the Alianceae family of great economic importance, and is the second most important vegetable crop in the world (FAO, 2006). However, making a significant contribution to the human diet, onions also have medicinal and functional properties (Lanzotti, 2006).

In Egypt onion is cultivated not only for local consumption, but also for export. Most of the area grown for export located in middle and upper Egypt. The early production of onion in the nile delta region gave the opportunity to increase bulbs yield for export. In Delta, Gizza 20 cv. Is a new cultivar well adapted for local conditions and show good uniformity in shape and color, this is may considered an exportable cultivar.
No doubt, the use of chemical fertilizers was boon for the past but ban for the present.

Where as organic fertilizers can be used in vegetable farming for safe food production and also sustain soil health. Using organic fertilizers the soil status can also be improved as it is rich in humus, different minerals, vitamins and growth substances that support excellent plant growth and production.

Humic acid is commercial product contains many elements which improve the soil fertility and increasing the availability of nutrient elements and consequently increased plant growth and yield. Moreover, humic acid particularly is used to ameliorate or reduce the negative effect of chemical fertilizers and some chemicals of soil. (Asmaa et al., 2010).

Seaweeds and various seaweeds extracts have been utilized in agricultural 


\section{A. Midan, et al.,}

practices since long. The extracts of marine macroalgae viz. Brown, red and green algae are known to have positive effect on growth and yield of crops. The brown algae are the most commonly used seaweeds in agriculture. Seaweed extracts contain different phytohormones like auxins, gibberellins, cytokinines, absesic acid, ethylene, betaine and polyamines and other growth promoters along with trace elements, vitamins, amino acids, antibiotics and micronutrients which enhance the yield and yield attributes of crops, when applied exogenously (Panda et al., 2012).

Phosphorous (P) and sulfur (S) are two necessary nutrients that increase the growth and yield of plants. Defect of this nutrients in soil, as usually compensated by using of chemical fertilizers but this fertilizers have harmful effects on the environment and decrease the quality of agricultural products. Therefore, biological fertilizers are more interested for using in agriculture ecosystems.

Endomycorrhyzal fungi are an integral part of most plant species in nature. It is well documented that application of mycorrhyzal fungi caused increases in water and nutrients absorption and translocation special phosphorous to host plant cells and improve growth as well as photosynthesis which reduce more assemelation. Also, mycorrhyza has synergistic effects with most of other microorganisms that have increasing effect on yield and yield components of most crops (Lukiwalid and Simanungkalit, 2002, Marulanda et al., 2003, Heggo and barakah, 2003).

The water treaded by magnetic field or pass through a magnetic devise called magnetized water. The effect of magnetic fields on running water have been observed for years. Decreases of soil salinity, increases in mobile forms of fertilizers, increases in crop yield and earlier vegetation periods can be achieved by magnetized water treatment.
The objective of this investigation was to increases onion growth and productivity in addition to improve bulbs quality via using some safety treatments to growing plants.

\section{MATERIALS AND METHODS}

The investigation was conducted at the experimental farm, Faculty of Agriculture, Menoufia University during 2014 and 2015 seasons. The experiment was laid out in randomized block design with three replicates. Onion transplants of Giza $20 \mathrm{cv}$. were transplanted on December and in 2014 and 2015, respectively. Transplants received the normal cultural practices of onion cultivation.

Six rows (3.5m long and $50 \mathrm{~cm}$ width) with a total square area $10.5 \mathrm{~m}^{2}$ were devoted for each experimental unit, the other two rows were considered as guard rows, two of witch were to study vegetative growth characteristics and chemical composition of plants, while the other two rows were left to yield investigation.

The treatments comprises of control where plants received mineral fertilizers according to the recommendation of Agriculture Ministry and five treatments which were seaweed extracts, mycorrhiza, magnetized water irrigation, organic fertilized and humic acid:

1- Seaweed extracts: Was added to the irrigation water $7 \mathrm{~cm} / \mathrm{L}$ twice after transplanting at 15 days intervals (Techno green group company, Cairo, Egypt, according to the recommendation of Agriculture Ministry).

2- Mycorrhiza: Was added at $3 \mathrm{~cm}^{3}$ for every transplant during transplanting, another $3 \mathrm{~cm}^{3}$ was added after 45 days from transplanting. Transplants roots were dipped in mycorrhiza solution before transplanting (Biological Unit of Ein Shams University). 


\section{3- Magnetized irrigation water: 1.4. Neck dry weight. \\ Irrigation of the treated plants with 1.5. Bulb fresh weight. magnetized water treated by a magnetic 1.6. Bulb dry weight. tube used for treating the water was 1.7. Total plant fresh weight. manetron (model U.T.I 1 inch diameter, \\ 1.8. Total plant dry weight.} output $4-6 \mathrm{~m}^{3} / \mathrm{h}$ and its strength $50 \mathrm{mT}$ ), Fig. (1) produced by magnetic technologies L.C.C., Russia, branch United Arab Emirates, was executed during growth period, irrigation according to the recommendation of Agriculture Ministry.

4- Organic fertilizer: A compost of debris sugars factories with compound A (energy compounds + mineral substances) and compound B (vegetables extract from natural sources contains felavonoids + afrofelavonoids). The compost will mixed with a compound $A$ and compound $B$ as the organic complex was added to the soil before transplanting and repeat the addition after 30 days from transplanting, obtained from Prolina Company for Agriculture development, Dr. Mohamed Sherif AbdelMaksoud .

NPK contents in the organic fertilizers were determined as data are presented in Table (1).

5- Humic acid: Humic acid was added to the soil at $2 \mathrm{~L} / \mathrm{fed}$ after transplanting for three times with 10 days intervals (according to the recommendation of Agriculture Ministry).

Thus, the experiment included five treatments in three replicates for each.

\section{Data recorded:}

During growth period, data were recorded for following items.

\section{I- Vegetative growth:}

Random 10 plants were dug out from each experimental unit 90 and 105 days from transplanting and subjected to the following measurements:

1.1. leaves fresh weight.

1.2. leaves dry weight.

1.3. Neck fresh weight.

\section{Enzyme activity in leaves:}

Chromatogram analysis of onion leaves obtained from plants treated with five different biological and biochemical agents was performed on HPLC apparatus, (Agilent Technologies 1262 Infinity) system, using a preceded by a Eclipse plus $₫$ C18 reversed phase guard column ( 4.6 by $10.0 \mathrm{~mm}, 3.5$ pm). The HPLC system consisted of a 1260 Quat Pump unit, Agilent Technologies 1260 diode array detector, fluorescence array detector, and a 1260 auto sampler which were controlled by ChemoStation for LC 3D system. Before samples injection, the column had been equilibrated with $90 \%(\mathrm{v} / \mathrm{v})$ water and $10 \%$ Acetonitril (solvent B). After injection, the samples were eluted at a flow rate of $1.0 \mathrm{ml} \min 1$ using an isocratic flow of $90 \%$ solvent $A$ and $10 \%$ solvent $B$ for 2 min, a linear gradient to $10 \%$ solvent $A$ and $90 \%$ solvent $B$ for $28 \mathrm{~min}$, followed by an isocratic flow for 5 min with $90 \%$ solvent B. For conducting HPLC analysis, $4 \mathrm{~g}$ of fresh leaves collected from each treatment were freeze dried using liquid nitrogen. The Freeze-dried leaves were grinded using pestle and mortal before mixing thoroughly with $5 \mathrm{ml}$ of ethyl acetate in plastic test tubes and gently hand shacked for $15 \mathrm{~min}$. After shacking, the suspension was centrifuged at $12,000 \mathrm{rpm}$ for 3 minutes. After separation, the suspension was filtrated into new tubes through 2 cotton layers and evaporated under vacuum to completion. The extracted compounds were then dissolved in $250 \mathrm{ul}$ methanol and $50 \mathrm{pi}$ of each chemical extraction analyzed by HPLC. Spectral analysis was conducted to compare the detected peaks with similar retention times in all extractions (Schouten et al., 2004) modified by (Selim 2010). 


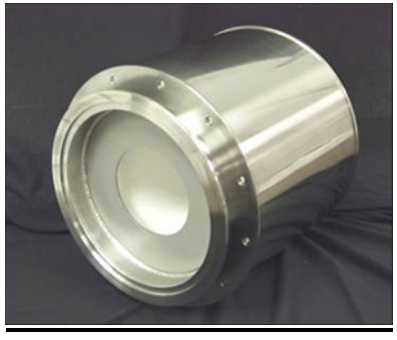

Fig. (1): Magnetic tube

Table (1) NPK contents in organic fertilizers used in 2014 and 2015 s4easons

\begin{tabular}{|l|l|l|l|l|l|}
\hline \multicolumn{3}{|c|}{2014} & \multicolumn{3}{c|}{2015} \\
\hline $\mathrm{N} \%$ & $\mathrm{P} \%$ & $\mathrm{~K} \%$ & $\mathrm{~N} \%$ & $\mathrm{P} \%$ & $\mathrm{~K} \%$ \\
\hline 1.68 & 0.74 & 0.62 & 3.29 & 0.54 & 0.98 \\
\hline
\end{tabular}

HPLC chemical standards of mixture of different chemical active compounds i.e. Acetone-DNPH, Acrolein-DNPH, 2, 5Dimethylbezaldehyde -DNPH, Formaldehyde- DNPH, IsovaleraldehydeDNPH, Propionaldehyde-DNPH and peroxides were used as references to compare the spectra pattern of obtained peaks within tested onion plants.

\section{Results}

\section{- Vegetative and growth criteria}

Different vegetative and growth criteria were recorded from two independent open field experiments conducted on two subsequent seasons (2013/2014 and 2014/2015).

The obtained results from first season experiment showed that either after 90 or 105 days, the highest leaves fresh and dry weight was observed on plants treated with mycorrhyza and magnetic water (Tables 2 , 3,4 , and 5). In contrary, organic fertilizers followed by humic acid resulted in lowest leaves fresh and dry weight (Tables 2, 3, 4, and 5).

Ninety days after transplanting, the highest fresh and dry weight of neck plant was observed on plants treated with mycorrhyza followed by magnetic water and seaweeds extracts (table 6, 7, 8 and 9). Similar results were recorded again on treated plants with mycorrhyza and magnetic water after 105 days post transplanting (Tables 6, 7, 8 and 9).

Similar to the results observed with leaves and neck fresh and dry weight, the highest weight of both fresh and dry bulbs was recorded on plants treated by mycorrhyza and magnetic water, respectively either 90 or 105 days post transplanting. Moreover, the least bulbs fresh weight was recorded on control plants while the lowest bulb dry weight was observed on plants treated with organic fertilizers (Tables 10, 11, 12 and 13). In harmony with the previous mentioned results, significant increase of whole plant fresh weight was noticed on plants treated with magnetic water as well as mycorrhyza treatments either 90 or 105 day (Tables 14, 15, 16 and 17).

Remarkable, similar results were obtained again from the second season experiment. Conversely, seaweeds extract affected positively both total plant fresh and dry weight more than the all other tested treatments in the second season experiment. 
Table (2): Leaves fresh weight as affected by some safety treatments during the winter season (2013/2014) at 90 and 105 days.

\begin{tabular}{|c|c|c|}
\hline Treatments & 90 days & 105 days \\
\hline Control & 85.24 & 116.80 \\
\hline Organic & 86.41 & 118.47 \\
\hline Mychorrhyza & 104.4 & 130.6 \\
\hline Magnetic water & 95.55 & 125.2 \\
\hline Humic acid & 93.73 & 118.25 \\
\hline $\begin{array}{c}\text { Sea weed extract } \\
\text { LSD value } \\
\text { at alpha }=5 \%\end{array}$ & 95.11 & 122.6 \\
\hline
\end{tabular}

Table (3): Leaves fresh weight as affected by some safety treatments during the winter season of 2014/2015 at 90 and 105 days.

\begin{tabular}{|c|c|c|}
\hline Treatments & 90 days & 105 days \\
\hline Control & 89.16 & 121.2 \\
\hline Organic & 99.46 & 128.8 \\
\hline Mycorrhiza & 103.6 & 148.8 \\
\hline Magnetic water & 106.8 & 143.4 \\
\hline Humic acid & 99.72 & 136.1 \\
\hline Sea weed extract & 102.9 & 142.8 \\
\hline $\begin{array}{c}\text { LSD value } \\
\text { at alpha }=5 \%\end{array}$ & 4.600 & 4.523 \\
\hline
\end{tabular}

Table (4): leaves dry weight as affected by some safety treatments during the winter (2013/2014) at 90 and 105days.

\begin{tabular}{|c|c|c|}
\hline Treatments & 105 days & 90 days \\
\hline Control & 6.613 & 6.813 \\
\hline Organic & 6.825 & 6.950 \\
\hline Mychorrhiza & 7.950 & 8.250 \\
\hline Magnetic water & 7.713 & 7.962 \\
\hline Humic acid & 7.115 & 7.825 \\
\hline Sea weed extract & 7.162 & 7.950 \\
\hline $\begin{array}{c}\text { LSD value } \\
\text { at alpha }=5 \%\end{array}$ & 0.9147 & 1.289 \\
\hline
\end{tabular}


A. Midan, et al.,

Table (5): leaves dry weight as affected by some safety treatments during the winter season of 2014/2015 at 90 and 105 days.

\begin{tabular}{|c|c|c|}
\hline Treatments & 90 days & 105 days \\
\hline Control & 4.625 & 5.100 \\
\hline Organic & 5.375 & 6.463 \\
\hline Mycorrhiza & 6.075 & 8.025 \\
\hline Magnetic water & 5.963 & 7.963 \\
\hline Humic acid & 5.600 & 7.225 \\
\hline $\begin{array}{c}\text { Sea weed extract } \\
\text { LSD value } \\
\text { at alpha }=5 \%\end{array}$ & 5.563 & 7.512 \\
\hline
\end{tabular}

Table (6): Neck fresh weight as affected by some safety treatments during the winter season (2013/2014) at 90 and 105 days.

\begin{tabular}{|l|c|c|}
\hline Treatments & 90 days & 105 days \\
\hline Control & 12.49 & 20.35 \\
\hline Organic & 14.70 & 23.75 \\
\hline Mychorrhiza & 19.35 & 26.65 \\
\hline Magnetic water & 17.95 & 26.33 \\
\hline Humic acid & 16.90 & 24.48 \\
\hline Sea weed extract & 16.88 & 24.83 \\
\hline $\begin{array}{l}\text { LSD value } \\
\text { at alpha }=5 \%\end{array}$ & 1.262 & 2.666 \\
\hline
\end{tabular}

Table (7): Neck fresh weight as affected by some safety treatments during the winter season of 2014/2015 at 90 and 105 days.

\begin{tabular}{|c|c|c|}
\hline Treatments & 90 days & 105 days \\
\hline Control & 12.38 & 25.67 \\
\hline Organic & 13.50 & 25.90 \\
\hline Mycorrhiza & 15.30 & 30.13 \\
\hline Magnetic water & 15.05 & 30.00 \\
\hline Humic acid & 14.32 & 26.75 \\
\hline Sea weed extract & 14.93 & 27.02 \\
\hline $\begin{array}{c}\text { LSD value } \\
\text { at alpha }=5 \%\end{array}$ & 1.747 & 2.521 \\
\hline
\end{tabular}


Table (8): Neck dry weight as affected by some safety treatments during the winter season (2013/2014) at 90 and 105 days.

\begin{tabular}{|c|c|c|}
\hline Treatments & 90 days & 105 days \\
\hline Control & 1.650 & 2.070 \\
\hline Organic & 1.813 & 2.243 \\
\hline Mychorrhiza & 2.263 & 2.855 \\
\hline Magnetic water & 2.225 & 2.827 \\
\hline Humic acid & 1.925 & 2.375 \\
\hline Sea weed extract & 2.037 & 2.773 \\
\hline $\begin{array}{c}\text { LSD value } \\
\text { at alpha }=5 \%\end{array}$ & 0.3137 & 0.5777 \\
\hline
\end{tabular}

Table (9): Neck dry weight as affected by some safety treatments during the winter season of 2014/2015 at 90 and 105 days.

\begin{tabular}{|c|c|c|}
\hline Treatments & 90 days & 105 days \\
\hline Control & 1.600 & 2.662 \\
\hline Organic & 1.663 & 2.938 \\
\hline Mycorrhiza & 2.300 & 3.475 \\
\hline Magnetic water & 2.175 & 3.275 \\
\hline Humic acid & 1.688 & 3.100 \\
\hline Sea weed extract & 1.900 & 3.300 \\
\hline $\begin{array}{c}\text { LSD value } \\
\text { at alpha }=5 \%\end{array}$ & 0.5512 & 0.3368 \\
\hline
\end{tabular}

Table (10): Bulb fresh weight as affected by some safety treatments during the winter season (2013/2014) of at 90 and 105 days.

\begin{tabular}{|l|c|c|}
\hline Treatments & 105 days & 90 days \\
\hline Control & 21.08 & 45.32 \\
\hline Organic & 22.15 & 47.92 \\
\hline Mychorrhiza & 27.77 & 60.33 \\
\hline Magnetic water & 27.42 & 57.72 \\
\hline Humic acid & 23.55 & 48.33 \\
\hline Sea weed extract & 23.60 & 53.60 \\
\hline $\begin{array}{l}\text { LSD value } \\
\text { at alpha = 5\% }\end{array}$ & 1.964 & 2.357 \\
\hline
\end{tabular}


A. Midan, et al.,

Table (11): Bulb fresh weight as affected by some safety treatments during the winter season of 2014/2015 at 90 and 105 days.

\begin{tabular}{|c|c|c|}
\hline Treatments & 90 days & 105 days \\
\hline Control & 19.50 & 40.42 \\
\hline Organic & 18.80 & 42.63 \\
\hline Mycorrhiza & 24.50 & 56.50 \\
\hline Magnetic water & 23.02 & 52.45 \\
\hline Humic acid & 22.65 & 45.20 \\
\hline $\begin{array}{c}\text { Sea weed extract } \\
\text { LSD value } \\
\text { at alpha }=5 \%\end{array}$ & 22.58 & 48.34 \\
\hline
\end{tabular}

Table (12): Bulb dry weight as affected by some safety treatments during the winter season 1 of 2013/2014 at 90 and 105 days.

\begin{tabular}{|l|c|c|}
\hline Treatments & 105 days & 90 days \\
\hline Control & 2.237 & 5.600 \\
\hline Organic & 2.350 & 6.048 \\
\hline Mychorrhiza & 3.150 & 6.988 \\
\hline Magnetic water & 2.787 & 6.637 \\
\hline Humic acid & 2.487 & 6.238 \\
\hline Sea weed extract & 2.700 & 6.338 \\
\hline $\begin{array}{l}\text { LSD value } \\
\text { at alpha }=5 \%\end{array}$ & 0.5355 & 0.8789 \\
\hline
\end{tabular}

Table (13): Bulb dry weight as affected by some safety treatments during the winter season of 2014/2015 at 90 and 105days.

\begin{tabular}{|l|c|c|}
\hline Treatments & 90 days & 105 days \\
\hline Control & 1.975 & 4.125 \\
\hline Organic & 2.125 & 4.737 \\
\hline Mycorrhiza & 2.775 & 6.280 \\
\hline Magnetic water & 2.300 & 6.113 \\
\hline Humic acid & 2.138 & 5.901 \\
\hline Sea weed extract & 2.287 & 5.987 \\
\hline $\begin{array}{l}\text { LSD value } \\
\text { at alpha }=5 \%\end{array}$ & 0.4189 & 0.689 \\
\hline
\end{tabular}


Table (14): Total plant fresh weight (Bulb -leaves-neck) as affected by some safety treatments during the winter season of 2013/2014 at 90 days.

\begin{tabular}{|l|c|c|}
\hline Treatments & 90 days & 105 days \\
\hline Control & 118.8 & 157.3 \\
\hline Organic & 123.2 & 165.1 \\
\hline Mychorrhiza & 151.4 & 191.5 \\
\hline Magnetic water & 140.9 & 188.2 \\
\hline Humic acid & 134.2 & 171.0 \\
\hline Sea weed extract & 135.6 & 181.0 \\
\hline $\begin{array}{l}\text { LSD value } \\
\text { at alpha }=5 \%\end{array}$ & 4.837 & 7.840 \\
\hline
\end{tabular}

Table (15): Total plant fresh weight (Bulb-leaves-neck) as affected by some safety treatments during the winter season of 2014/2015 at 90 and 105 days.

\begin{tabular}{|l|c|c|}
\hline Treatments & 90 days & 105 days \\
\hline Control & 121.0 & 172.3 \\
\hline Organic & 131.8 & 182.3 \\
\hline Mycorrhiza & 143.3 & 215.4 \\
\hline Magnetic water & 144.9 & 208.9 \\
\hline Humic acid & 136.7 & 190.1 \\
\hline Sea weed extract & 140.4 & 198.1 \\
\hline $\begin{array}{l}\text { LSD value } \\
\text { at alpha }=5 \%\end{array}$ & 5.486 & 6.012 \\
\hline
\end{tabular}

Table (16): Total plant dry weight (Bulb-leaves-neck) as affected by some safety treatments during the winter season 1 of 2013/2014 at 90 and 105 days.

\begin{tabular}{|l|c|c|}
\hline Treatments & 90 days & 105 days \\
\hline Control & 11.49 & 14.48 \\
\hline Organic & 11.56 & 14.75 \\
\hline Mychorrhiza & 14.46 & 16.77 \\
\hline Magnetic water & 13.39 & 16.11 \\
\hline Humic acid & 13.16 & 15.05 \\
\hline Sea weed extract & 13.28 & 15.57 \\
\hline $\begin{array}{l}\text { LSD value } \\
\text { at alpha }=5 \%\end{array}$ & 1.195 & 1.305 \\
\hline
\end{tabular}


A. Midan, et al.,

Table (17): Total plant dry weight (Bulb-leaves-neck) as affected by some safety treatments during the winter season of 2014/2015 at 90 and 105 days.

\begin{tabular}{|c|c|c|}
\hline Treatments & 90 days & 105 days \\
\hline Control & 9.575 & 12.66 \\
\hline Organic & 9.962 & 13.26 \\
\hline Mycorrhiza & 12.34 & 15.46 \\
\hline Magnetic water & 12.21 & 15.10 \\
\hline Humic acid & 11.453 & 13.94 \\
\hline Sea weed extract & 11.04 & 14.49 \\
\hline $\begin{array}{c}\text { LSD value } \\
\text { at alpha }=5 \%\end{array}$ & 1.107 & 1.352 \\
\hline
\end{tabular}

\section{- Chromatogram analysis}

The results demonstated also that, all tested treatments induced the accumulation of peroxidase enzyme within individual treated plants. The highest accumlation levels was detected with seaweeds and mycorhyza treatemnts followed by organic fertiliyers and humic acid. In contary, lowest accumulation of peroxidase substance was recorded on plants treated with magnetic water (Fig. 2).

Chromatogram analysis showed also that seaweeds extract was superior comparing to the all other tested subtances in aspect to increasing levels of total phenol componds on treated onion plants while the lowest concentration of phenolic compounds was recorded by humic acid (Fig. 3).

\section{Discussion}

The obtained results showed that mycorrhyza and magnetic water were superior comparing to the all other treatments. Thus the most highest vegetative and growth criteria recorded with the mycorrhyza followed by the magnetic water. In contrary, the lowest fresh and dry weight of leaves, bulbls and neck organs were observed on plants treated with control, humic and organic fertilizers, respectively. Remarkable, in second season trail the results demonstrated that seaweed extracts resulted in the highest data values with treated plants in comparing to control as well as the rest of other treatments.

These results are in agreement with the study of Watts-Williams et al., (2014) who demonstrated that mycorrhyza fungi play a significant role in increasing and improving the plant growth. Selim $(2009,2013)$ and Zayed (2010) reported also that magnetized water irrigation increased the accumulation of different important chemical ingredients as carbohydrates which lead to increasing the dry weight of treated plants.

Furthermore, in 2012, Dagro and Rekesh mentioned that seaweeds application enhanced dry matter accumulation on treated onion plants.

On the other hand, in the present study, the obtained results seaweeds and mycorhyza fungi recorded the highest accumulation of peroxidase and total phenols.

Certain mutualistic endophytic isolates belonging to specific species of Trichoderma, Gliocladium, Fusarium, Mucor, Penicillium, Aspergillus, Stachybotrys, and mycorrhzya genera have the potential for application in agricultural systems besides the traditional chemical pesticides. Some can be beneficial with regard to tolerating biotic and a biotic stress caused by drought, 
salinity, minerals deficiency and pathogen invasion through modulating an array of physiological, biochemical and morphological processes (Oelmüller, et al., 2009; Sherameti et al., 2005., Lukiwatid and simamyngkalit., 2002) resulting in the accumulation and translocation of assimilates, osmotic adjustment, maintenance of cell wall elasticity and the increase of the water use efficiency by the host plant. Others can support the plant in coping with biotic stress conditions.

Moreover, many of seaweeds (marine algae) attracted the interest of scientists as natural sources of different bio-active compounds. Therefore they are candidate to be promising bio-stimulator agents (Michael et al., 2005; El-gamal, 2010). Many bioactive compounds have been identified in seaweeds; antioxidants are often, reducing agents such as thiol, ascorbic acid or poly phenols (Hu, 2008; Li et al., 2011). Of the beneficial antioxidant compounds, phenolic compounds widely exist in plants and have been considered to have high antioxidant capacity and free radical scavenging capacity (Kahkonen et al., 2001).

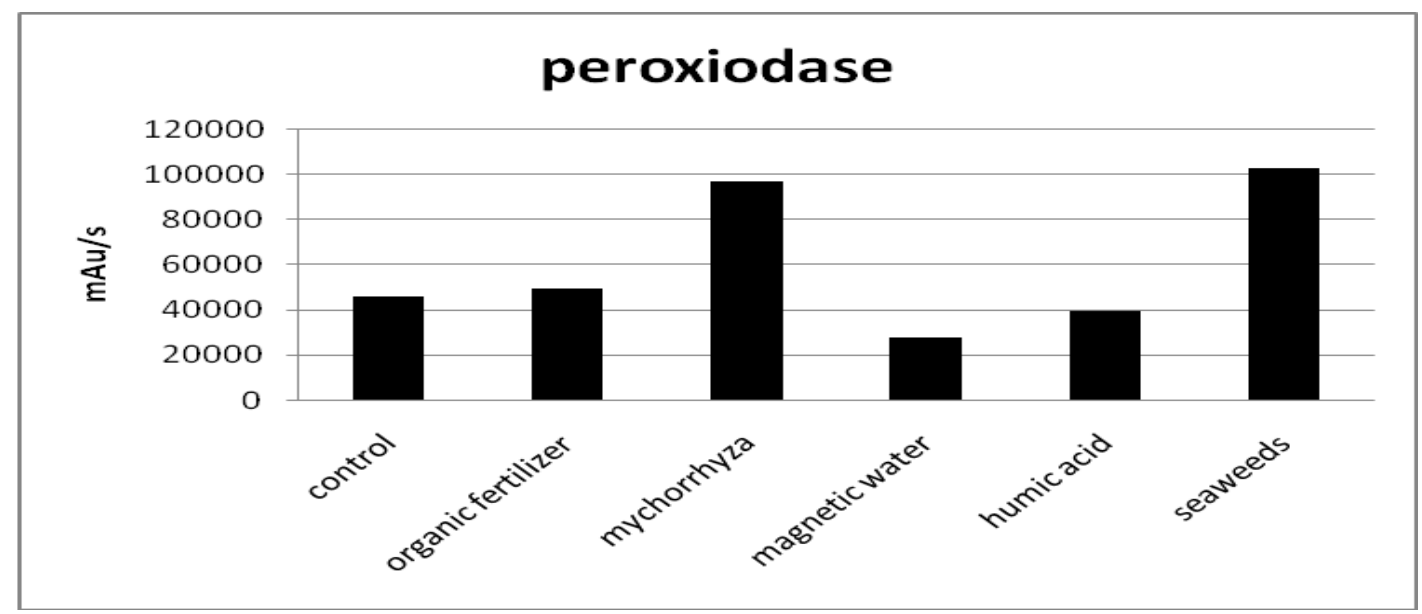

Figure (2): Accumulation of peroxidase enzyme within individual treated onion plants.

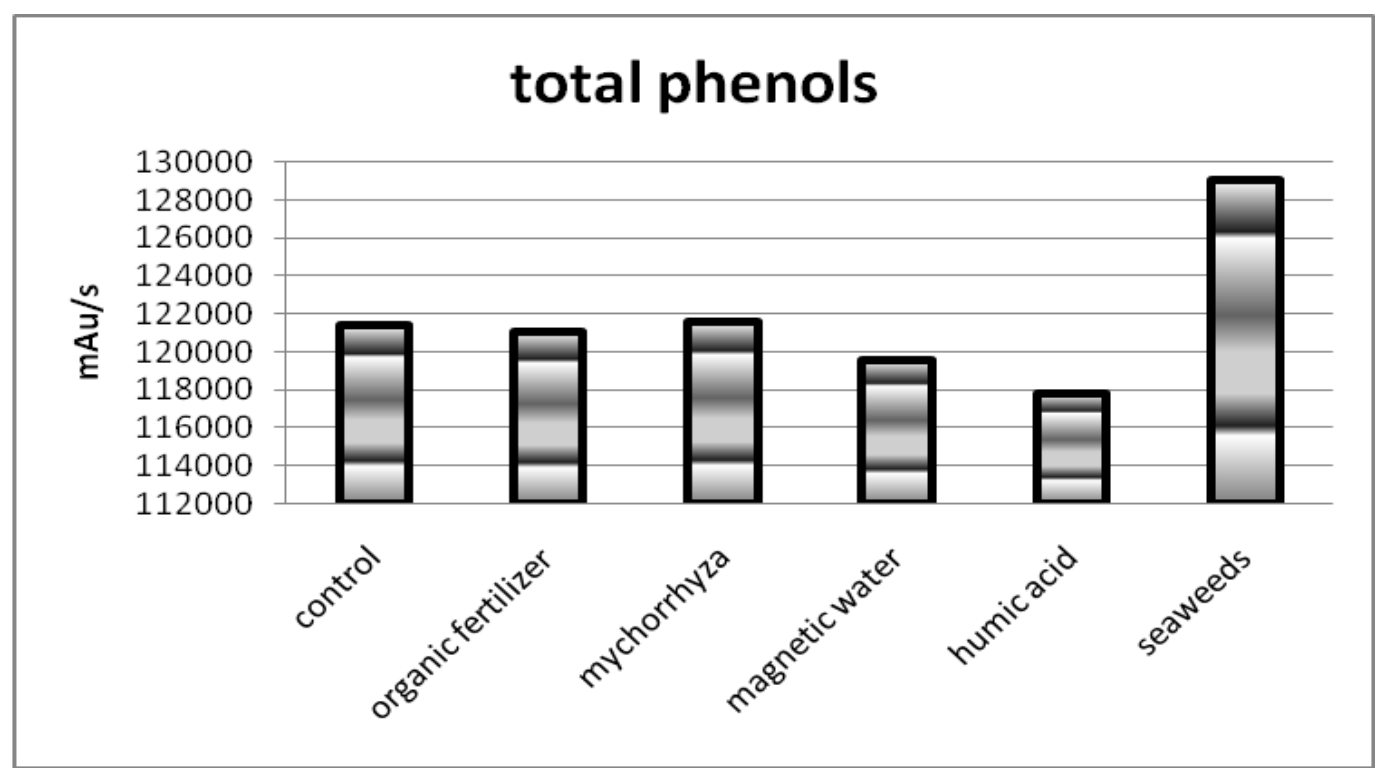

Figure (3): Accumulation of total phenols compounds within individual treated onion plants. 


\section{A. Midan, et al.,}

Recently, Macartain et al. (2007) proved that seaweeds generally have high concentrations of $\mathrm{C}, \mathrm{K}, \mathrm{Mg}, \mathrm{Na}, \mathrm{Cu}, \mathrm{Fe}, \mathrm{I}$, and $\mathrm{Zn}$. The presence of these value nutrient elements within seaweeds (marine Algae) make them excellent organic fertilizers and could explain the positive influence of the tested seaweeds on onion fresh and dry weights. Additionally, seaweeds algae, as bio/stimulators agents may increase RWC, antioxidant enzymes i.e. peroxidase and total phenols as well as increasing cinamic acid concentrations. Moreover increases in onion leaves, neck, bulb and total plants fresh and dry weight was demonstrated in present study as well (Bhattacharya et. al., 2013).

\section{REFERENCES}

Asmaa Abdel Magoud, M.R., A.S. Tantawy, M.H. Magda and A.M. Hoda (2010). Seaweed extract improves growth, yield and quality of different watermelon hybrids. Res. J. Agric. and Bio. Sci., 6:161-186.

Bhattacharyta, S., P.R. Deep, B. Nayak, Monalisa Panigrahi and B. Mohapatra (2013). Antimicrobial activity of two diazotrophic Cyanobacteria against Staphylococcus aureus. Int. J. Med. Arom. Plants, 3(2): 283-292.

Dagro, B.S. and Rakesh K. Mandeadia (2012). Effect of seaweed extract on growth and yield of onion. International Journal of Farm Science, 2(1):59-64.

El-gamal, A.A. (2010). Biological importance of marine algae. Saudi Pharmaceutical Journal, 18 (1): 1-25.

FAO, Food Agricultural Organization, (2006). Statistics Division. Datas Agricolas De FAOSTAT. http://faostat.fao.org

Heggo, A.M. And F.N. Barakah (2003). Phosphate activity as affected by plant root exudates, arbuscular mycorrhiza and P- fertilizer source. In: Conference of Enzymes in the Enviroment. Activity, Ecology and Applications. Praha, Czeh Republic, 111p.
Hu, C. C., J.T. Lin, F. J. Lu, F. P. Chou and D.J. Yang (2008). Determination of carotenoids in Dunaliella Saline cultivated in Taiwan and antioxidant capacity of the algal carotenoid extract. Food Chemistry, 109:439-446.

Kahkonen, M. P., A. I. Hopia and M. Heinonen (2001). Berry phenolics and their antioxidant activity. J. Agric. Food Chem., 49: 4076-4082.

Lanzotti, V. (2006). The analysis of onion and garlic. Journal of Chromatogrphy. A, 112:3-22.

Li, Y. X., I. Wijesekara, Y. Li and S. K. Kim (2011). Phlorotannins as bioactive agents from brown algae. Process Biochemistry , 46:2219-2224.

Lukiwatid, D.R. and R.D.M. Simanungkalit (2002). Dry matter yield, N and P uptake of soybean with Glomus manihotis and Bradyrhizobium japonicum. In: $17^{\text {th }}$ Word Congress of Soil Science, 14-21 August, Thailand. pp, 1190-1198.

Macartain, P., C.I.R. Gill, M. Brooks, R. Campbell and I.R. Rowlamd (2007). Nutritional value of edible seaweeds. Nutritional Reviews, 65(12): 535-543.

Marulanda, A., R. Azcon and J.M. RuicLozano (2003). Contribution of six arbscular mycorrhizal fungal isolates to water uptake by lactuca sativaplants under drought stress. Plant Physiol., 119:526-533.

Michael, T.M., M.M. John and P. Jack (2005). Brock microbiology of microorganisms. $11^{\text {th }}$ Edition, New Jersey. ISBN: 13-978-0226701479.

Oelmu“ller, R., I. Sherameti, S. Tripathi and A. Varma (2009). Piriformospora indica, a cultivable root endophyte with multiple biotechnological applications. Symbiosis, 49: 1-17.

Panada, D., K. Pramanik and B. R. Nayak (2012). Use of seaweed extracts as plant growth regulators for sustainable agriculture. International Journal of Bioresource and Stress Management. 3(3): 404-411. 
Schouten, A., G. van den Berg, VeroniqueEdelHermann, Christian Steinberg, Nadine Gautheron, Claude Alabouvette C.H., (Ric) de Vos, Philippe Lemanceau and Jos M. Raaijmakers (2004). Defense responses of Fusariumoxysporum to 2,4Diacetylphloroglucinol, a Broad-spectrum antibiotic produced by Pseudomonas felourescens. The American Phytopathological Society MPMI, 17(11):1201-1211.

Selim, Dalia A. (2013). Physiological response of wheat plants to magnetic technologies under salt stress conditions. Ph.D. Thesis, Botany Department, Fac. of Agric., Minufiya University.

Selim, Dalia A., A.A. Gendy, A.M. Maria and E.M. Mousa (2009). Response of pepper plants to magnetic technologies $1^{\text {st }}$ Nile Delta conf. on Export crops, Fac. of Agric.; Minufiya Univ., 89-104.

Selim, M.E. (2010). Biological, chemical and molecular studies on the systemic induced resistance in tomato against Meloidogyne incognita caused ( by the endophytic Fusarium oxysporum, Fol62.
Ph D Thesis, University of Bonn, Germany.

Sherameti, I., B. Shahollari, Y. Venus, L. Altschmied, A. Varma and R. Oelmu"ller (2005). The endophytic fungus Piriformospora indica stimulates the expression of nitrate reductase and the starch-degrading enzyme glucanwater dikinase in tobacco and Arabidopsis roots through a homeodomain transcription factor which binds to a conserved motif in their promoters. Journal of Biology Chemistry 280: 26412647.

Trough, E. and A.M. Meyer (1939). Improvement indenies colorimetric method for phosphorus and arsenic. $2^{\text {nd }}$ Eng. Chem. Anal., Ed., 1:136-139.

Wettstein, D. (1957). Chlorophyll, letal under sumbikro svopische formmech cellderplastiden. Expil.; Cell Res., 12:427-433.

Zayed, M.A.M. (2010). Physiological and chemical studies on some plants as affected by magnetic treatment. M.Sc. Science (Plant Physiology), Minufiya University (2010), pp:46-209.

\section{التأثيرات الفسيولوجية والبيوكيميائية لبعض المعاملات الآمنة علي نباتات البصل}

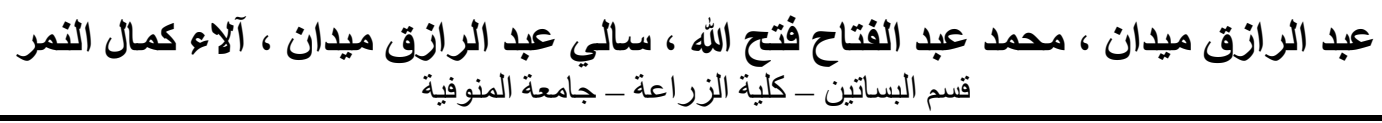




\section{A. Midan, et al.,}

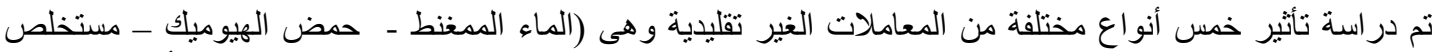

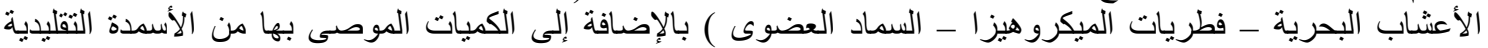

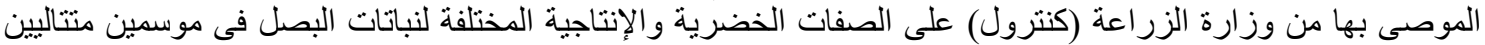

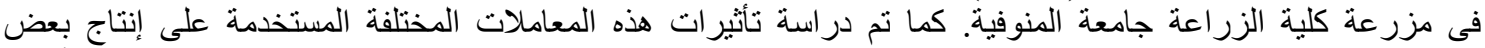

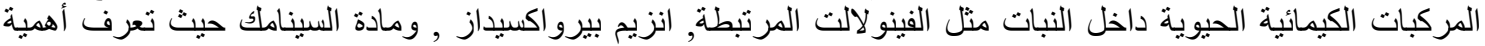

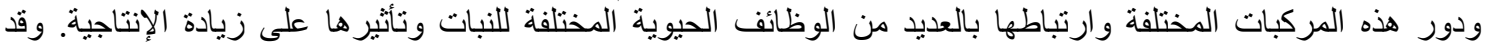

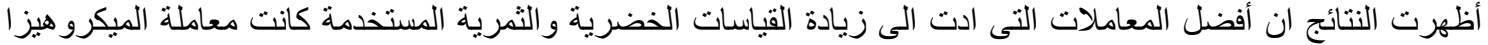

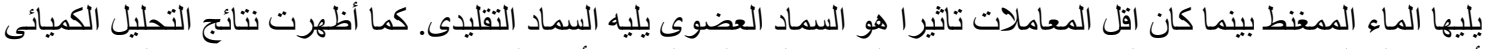

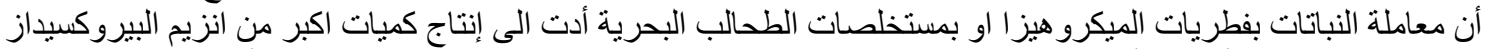

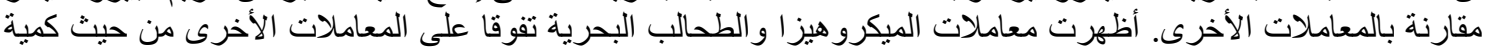

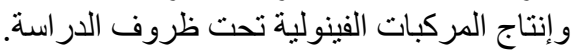

